\title{
Hidroelektrik enerji santralleri sırasında bozulan sahalarda peyzaj onarım sürecinin Kabaçağlayan Şelalesi örneğinde incelenmesi
}

\author{
Metin Demir a,", Mehmet Akif Irmak ${ }^{a}$, Hasan Yılmaz ${ }^{a}$, Turan Karadeniz
}

\begin{abstract}
Özet: Gelişen sanayi, teknoloji ve hızlı nüfus artışı ülkemizde enerji ve hammaddeye olan ihtiyacı arttırmıştır. Ancak, yapılan faaliyetler doğal çevrede birçok değişime neden olmakta, bu değişimler ise doğayı olumsuz etkilemektedir. Bu olumsuz etkiler, doğa onarım ve rehabilitasyon çalışmaları ile büyük ölçüde onarılabilmekte, biyolojik üretim potansiyelleri ve peyzaj kalitesi arttırılabilmektedir. Araştırma alanı olarak seçilen Kabaçağlayan şelalesi, Giresun ili, Dereli ilçesinde bulunmakta olup, şelale güzergahında bulunan Hidroelektrik santral regülatörü, kazı fazlası malzemeleri şelale çevresinde tahribata sebep olmuştur. Bu çalışma ile alanda meydana gelen tahribatın giderilmesi için uygun peyzaj onarım yöntemi belirlenmiş ve detaylandırılmıștır. Çalışmada biyolojik onarım süreci 5 kısımda ele alınmıştır. Yapılan değerlendirmeler sonucunda alan için peyzaj onarım çalışmaları kapsamında, toplam 14.627,81 $\mathrm{m}^{2}$ alanın ıslah edilmesi önerilmiştir. Rehabilitasyon alanının $5.719,67 \mathrm{~m}^{2}$ lik bölümünde ağaçlandırma çalışması, $7.852,36 \mathrm{~m}^{2}$ lik alanında ise çelik ağlarla şev koruması yapılması planlanmıştır. Ayrıca onarım sahası için rekreasyonel odaklı peyzaj projesi hazırlanmıştır. Benzer problemlerin yaşandığı onarım alanları için bazı önerilere yer verilmiştir.
\end{abstract}

Anahtar kelimeler: Peyzaj onarımı, Biyolojik onarım, Hidroelektrik santral, Kabaçağlayan Şelalesi

\section{Evaluation of landscape restoration process in damaged areas during the construction of hydroelectric power plants in the sample of Kabaçağlayan Waterfall}

\begin{abstract}
Evolving industry, technology and the rapid population growth have increased the demand for energy and raw materials in our country. However, the activities cause many changes in the natural environment, so these changes adversely affect the nature. These negative effects can be largely restored by repairing nature and through rehabilitation works. In this way, biological production potential and landscape quality can be improved. Kabaçağlan waterfall, chosen to be the research area, is located in Dereli district in the city of Giresun. Hydroelectric power regulator on the waterfall route, excavation of excessive materials has caused destruction around the waterfall. In this study, landscape restoration method has been determined and detailed to overcome the resulting damage in the area. Biological repairing process is discussed in this study as well. The result of the evaluation, in the context of landscape restoration works, rehabilitation has been proposed for the total area of $14627.81 \mathrm{~m}^{2}$, in $5719.67 \mathrm{~m}^{2}$ and $7852.36 \mathrm{~m}^{2}$ of which were left for reforestation efforts and slope protection made with steel mesh, respectively. In addition, recreational oriented landscape project was prepared for repairing area. Some proposals are given for repairing areas where similar problems are seen.

Keywords: Landscape repairment, Biological rehabilitation, Hydroelectric power, Kabaçağlayan Waterfall
\end{abstract}

\section{Giriş}

Ülkemizde ve bütün dünyada sosyal ve ekonomik kalkınmanın temel göstergesi olan enerjiye gün geçtikçe daha çok ihtiyaç duyulması, enerji kaynaklarının sınırlı olması ve sürekli tüketilmesi gerçeğinin daha geniş kesimlerce anlaşılmas 1, ülkeleri; enerji politikalarını yeniden gözden geçirmeye ve enerjiyi daha etkin kullanmaya yöneltmiştir. Hidroelektrik enerji kaynakları; temiz ve yenilenebilir olmas1, yerli doğal kaynak olması, iş letme ve bakım giderlerinin düşük olması, fiziki ömürlerinin uzun oluşu gibi nedenlerle kömür, doğal gaz ve petrol gibi fosil yakıtlardan üretilen enerjiye göre daha çok çevreyle dost enerji kaynaklarıdır (Acar ve Doğan, 2008; Aksungur vd, 2011).

Hidroelektrik enerji üretiminin doğal, tarihi, kültürel varlıklar ve sosyoekonomik çevre üzerinde, boyutları projeden projeye değişen birçok etkisi mevcuttur (Demir ve Güven, 2014). Hidroelektrik santrallerin doğaya en az zarar veren enerji üretim yöntemlerinden biri olduğu varsayılmaktadır. Ancak hidroelektrik santrallerinin yapım aşamalarında meydana gelen tahribatlar nedeni ile oldukça olumsuz durumlar da meydana gelebilmektedir. Ayrica yapım aşamasından sonra da bir takım olumsuzluklar görülebilmektedir. Su alma yapıları olan regülatörler, küçük birer baraj gibi davranarak akarsuların bütünlüklerini bozmaktadır. Su alma yapıları ile suyun yeniden akarsuya

\footnotetext{
$\triangle$ a Atatürk Üniversitesi, Mimarlık ve Tasarım Fakültesi, Peyzaj Mimarlığı Bölümü, 25240, Erzurum

${ }^{\text {b }}$ Abant İzzet Baysal Üniversitesi, Ziraat Fakültesi, Bahçe Bitkileri Bölümü, Bolu

@ ${ }^{*}$ Corresponding author (İletişim yazar1): metin @ atauni.edu.tr

$\checkmark$ Received (Geliş tarihi): 08.03.2016, Accepted(Kabul tarihi): 16.08.2016
}

Citation (Atıf): Demir, M., Irmak, M.A., Yilmaz, H., Karadeniz, T., 2017. Hidroelektrik enerji santralleri sirasinda bozulan sahalarda peyzaj onarım sürecinin Kabaçağlayan Şelalesi örneğinde incelenmesi. Turkish Journal of Forestry, 18(1): 63-73 DOI: $10.18182 /$ tif. 224624 
verildiği alan arasında suyun çok büyük miktarını alarak akarsuyun doğal akımını değiştirmektedir (Ürker ve Çobanoğlu, 2012).

Ünlü ve Kızgut (2000)'a göre açık enerji ve maden çalışmalarından sonra alanda tarihi değeri olan yapılar ve doğal değerler kaybedebilmektedir. Örtü-kazı çalışması sonucu, sahadaki flora ve fauna zarar görerek, oluşturulan şevler büyük çukurlar meydana getirmektedir. Hiçbir onarım çalış ması yapılmaz ise, önceden yeşil olan bölge taş ve toprak yığını haline gelmektedir. Bu tür bir bölgenin kendiliğinden bitkisel hayatı barındırmas 1 için as gari 40-50 y1llık bir sürenin geçmesi gerekmektedir (Özbey, 2005).

Türkiye'de bütün HES'ler inşaata başlanmadan önce kapsamlı bir düzenleme ve inceleme sürecinden geçmektedirler. Elektrik Üretim Hakkı ve Su Kullanım Hakkı Anlaşması imzalamaya hak kazanan firmalar Çevresel Etki Değerlendirme (ÇED) Raporlarını hazırlamaya başlarlar. Çevre etki değerlendirme raporları, çevre ile yapının karşılıklı etkilerini açıklayan raporlardır. ÇED, belirli bir proje veya gelişmenin, çevre üzerindeki önemli etkilerinin belirlendiği bir süreçtir. Bu süreç, kendi başına bir karar verme süreci olmayıp, karar verme süreci ile birlikte gelişen ve onu destekleyen bir süreçtir (Aks ungur vd., 2011; Ürker ve Çobanoğlu, 2012). Ön ÇED'e tabi HES projeleri için, Orman ve Su İşleri Bakanlığı, Doğa Koruma ve Milli Parklar Genel Müdürlüğü tarafindan; aşağıda sunulan ana başliklar incelenir;

1. Proje alanının yer aldığ 1 ekos is temin ekolojik ihtiyaçları,

2. Hassas, endemik, nes li tehlike altındaki bitki ve hayvan türleri,

3. Proje yakınında korunan alan olup olmamas1, sınırları, iliş kisi ve varsa yönetim planları,

4. Projenin etki alanı (tünel uzunluğu, mansap değerleri, muhtemel rezervuar alanı $\mathrm{vb}$.),

5. Akarsuyun debisi,

6. Çevresel akış değerlendirmesi,

7. Çevresel akış miktarı

Ayrıca, aynı Bakanlık tarafindan "HES projeleri ve diğer faaliyet talepleri için değerlendirme raporu", "Peyzaj onarım değerlendirme raporu", istenir. Peyzaj onarımının temel hedefi, bozulan arazilerin, ekonomik, ekolojik ve estetik değerlerine yeniden kavuşturulmasıdır. Faaliyet öncesi, faaliyet yapımı ve sonras inda yapılması gereken bir dizi planlama ve uygulama çalışmalarını kapsar. Bu çalışmaların özünde, alana yeni bir kullanımın kazandırılması ya da faaliyet öncesi alan kullanımının canlandırılması yatmaktadır (Akpınar ve Çelem, 2000).

Yapılan çalışmada; Giresun İli, Dereli İlçesi, Kabaçağlayan Şelalesi yakınlarında gerçekleştirilen HidroElektrik-Santrali (HES) tesisinin, şelale çevresinde meydana getirdiği tahribatların onarımı ve rekreasyona kazandırılması amaçlanmıştır. Regülâtör kurulması aşamasında, ulaşım yolu ve tünel açılması sıras inda meydana gelen hafriyatın orman izni olan kazı fazlası malzeme alanına bırakılması ile tahrip olan doğal peyzajın, ekolojik ve estetik değerlerinin yeniden kazandırılması için yapılması gerekenler belirlenmiştir. Ayrıca, çevreye uyum sağlayan bir arazi morfolojisinin tasarlanması ve tahrip edilen yüzeylerin bitkilendirilmesinden (Biyo-restorasyon) sonra, saha eski haline dönüşümü için uygun yöntemler ortaya konulmuş tur.

\section{Materyal ve yöntem}

Araştırma alanı olan Baybahan regülatörü kazı fazlası malzeme alanı peyzaj onarım sahası, Giresun ili, Dereli İlçesi, Tepeköy Köyü, Baybahan yaylası sınırları içeris inde bulunmaktadır. Onarım sahasının konumunu gösterir yer haritası Şekil 1'de, alandan görünümler ise Şekil 2'de verilmektedir.

Çalışma alanı, Doğu KaradenizBölgesi'nde yer almakta olup, 1/25.000 Ölçekli Giresun-G40c4 no'lu paftada bulunmaktadır. Peyzaj onarım alan1, 23.657,87 $\mathrm{m}^{2}$ olup, Giresun İline $80 \mathrm{~km}$, Dereli ilçesine ise $48 \mathrm{~km}$ mesafededir.

Peyzaj Onarım Projesinin arazi çalışması, 2014 yılında, Giresun ili, Dereli İlçesi, Tepeköy Köyü, Baybahan yaylas inda, proje ekibi tarafindan gerçekleştirilmiş tir. Proje ekibi tarafindan alana ait önceki çalışmaların verileri toplanmış, arazi sörveyleri ve vejetas yon tespiti ile mevcut durum analizi yapılmıştır.

Araştırma alanının Peyzaj Onarım Projesinin oluşturulması aşamasında, (Kocadagistan vd., 2007; Uzun ve Y1lmaz, 2009; Deniz ve Şen, 2011; Anonim, 2012; Ulusoy ve Ayaşlıgil, 2012)'nin çalışmalarından faydalanılmıştır. Yöntem altı aşamadan oluşmuştur. Araştırmada izlenen yöntemin akış şeması Şekil 3.'de verilmiştir.

Çalışmanın ilk iki aşamasında araştırma alanın seçimi ve amacının belirlenmesi oluşturmaktadır. Üçüncü aşamada çalışma alanına ve yöntemine ilişkin literatür çalışması yapılmış alana gidilerek arazi gözlemleri ve ilgi gurupları ile görüşmeler yapılmıştır. Dördüncü aşamada araştırma alanında "Doğal Peyzaj Envanteri" olan, flora, fauna, topografya, jeoloji, hidroloji, toprak, iklim, araştırılarak tanımlanmıştır. Alana yönelik gerek kamu kurumlarından gerekse bilimsel araştırmalardan elde edilen verilerden, sayısal olamayan veriler sayısallaştırma işlemleri yapılıp, veri tabanlarında biriktirilerek, Coğrafik Bilgi Sistemi (CBS) ortamına aktarılmıştır. Çalışmada CBS tekniklerinden faydalanılmıș olup, ArcGIS 10.2 yazılımı ve uzanımları kullanılmış tır.

Beşinci aşamada değerlendirme ve peyzaj onarım hedeflerinin belirlenmesi yapılmıştır. Altıncı ve son aşama ise Biyolojik ve Teknik Onarım (Biyorestorasyon) kısmından oluşmaktadır.

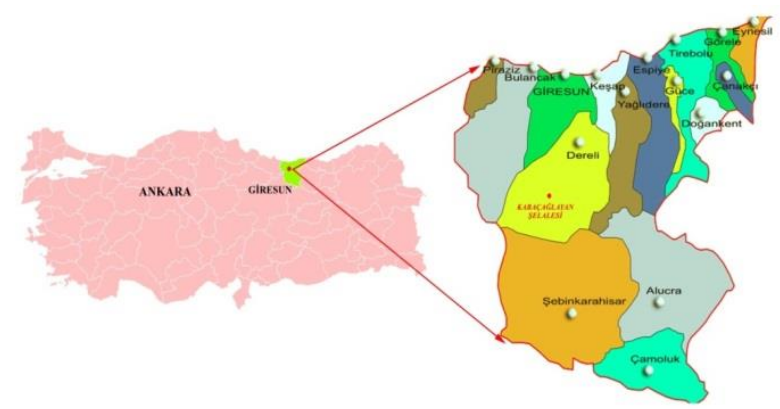

Şekil 1. Peyzaj onarım sahası 


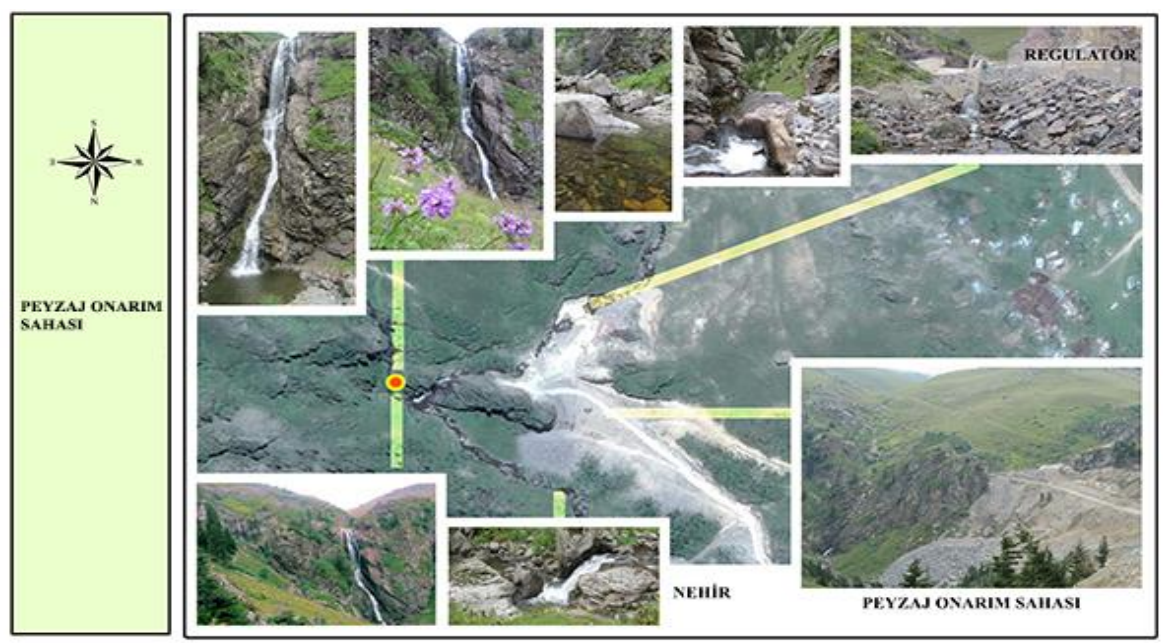

Şekil 2. Araştırma alanından görünümler
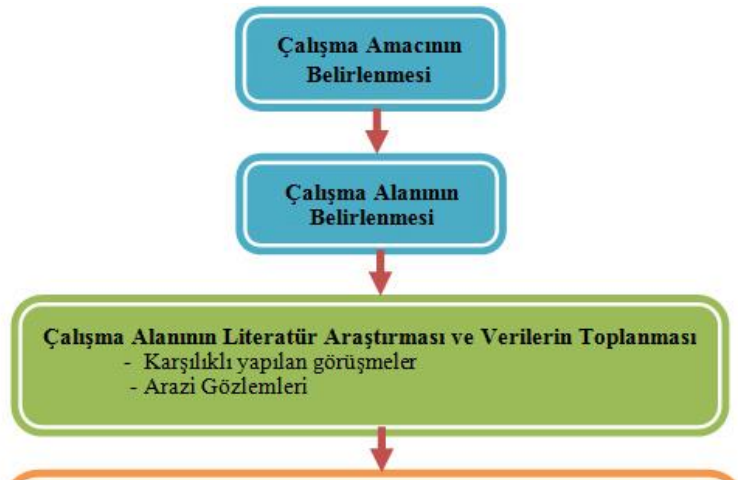

\section{Doğal Peyzaj Envanteri}

- Flora,

- Fauna,

- Topografya

- Hidroloji,

- Toprak

- Iklim

$\downarrow$

CBS Programı Kullanılarak Verilerin

Sayılaștırılması ve Haritaların Olușturulmas

1

Değerlendirme ve Peyzaj Onarım Hedeflerinin Belirlenmesi

Biyolojik ve Teknik Onarmm (Biyorestorasyon)

1. Ağaçlandırma ve fidan dikimleri

2. Çelik Ağlarla Şev Koruması Yapilması

3. Şevlere orman toprağı serpilmesi

4. Şelale için açılan yolun zemin döşemesi

5. Peyzaj projesinin uygulaması

Şekil 3. Araştırma yönteminin akış şeması

\section{Araş tırma bulguları}

Peyzaj Onarım sahası ile ilgili olarak Orman ve Su İşleri Bakanlı̆g 1 , Giresun Orman Bölge Müdürlüğü tarafindan verilen 1/25.000 Ölçekli Meşcere Haritası Şekil 4'de verilmiştir. Peyzaj Onarım sahası Giresun Orman Bölge Müdürlüğü, Dereli Orman İşletme Şefliğine bağll, İkisu Orman İşletme Şefliği serisi içerisinde bulunmaktadır. Onarım sahası 122 ve 126 Bölmeleri içerisinde olup, meşçere tipleri ise BL-2: Bozuk ladin koru mesceresi ve OT: Ağaçsız Orman Toprağ 1 olarak tespit edilmiştir (Anonim, 2013). Proje ekibinin arazi çalışmaları sıras ında elde ettiği bitki örneklerinin teşhisleri yapılmıştır. Teşhis edilen yaygın yayılış gösteren başlıca ağaç ve çalı bitkilerin çekilen fotoğraflardan bazıları ise Şekil 5'de verilmiştir.

Proje alanındaki tespit edilen bitki türlerinden bazıları, doğu ladini (Picea orientalis L.), mürver (Sambucus nigra L.), yabani ahududu (Rubus idaeus), mor çiçekli orman gülü (Rhododendron ponticum L.), orman sarmaşığ 1 (Hedera helix L.), ada çayı( Salvia verticillata L. subsp. verticillata), meşe (Quercus L.), kartal eğrelti (Pteridium aquilinum L. Kuhn), sarıçiçekli ormangülü (Rhododendron flavum Don.) olarak tespit edilmiştir.

\subsection{Fauna}

Dereli İlçesi sınırları içerisinde olan çalıșma alanı olan hayvan varlığ sahip olmaktadır. İlçenin orman alanlarında yaban keçisi (Capra aegagrus), kızılgeyik (Cervus) ve karaca (Capreolus capreolus) türlerine rastlamaktadır. Araştırma alanında ayrica, yabanitavşan (Lepus), kurt (Canis), yaban domuzu (Sus scrofa), çakal (Canis aureus), tilki (Vulpes vulpes), porsuk (Meles meles), ayı (Ursus arctos), alacasansar (Vormela peregusna), sincap (Sciurus anomalus), gelincik (Mustela navilis) türleri bulunmaktadır.

Alanın yakın çevresinde kaydedilen kuş türlerinden; Akleylek (Ciconiaciconia), atmaca (Accipiter nisus), k1zil şahin (Buteo rufinus), kaya güvercini (Columba livia), kuzgun (Corvus corax), kerkenez (Falco tinnunculus), kukumav (Athena noctua), arıkuşu (Merops apiaster), ibibik çavuşkuşu (Upupa epops), albaş ağaçkakan (Dendrocopus medius), saka (Carduelis carduelis) yörede görülür (Anonim, 2014a).

\subsection{Topografya, jeoloji ve jeomorfoloji}

Dereli İlçesi sınırları içerisinde olan proje sahasında dağlar dik yamaçlar halinde yüks elir. Bu dağlar Dereli ilçesi içinden geçen Aksu deresi vadisi etrafinda suralar halinde, kimi yerde kuzeyden güneye, kimi yerde batıdan doğuya kıvrımlar halinde uzanırlar. Saha aşınmanın doğal sonucu 
olarak dik ve devamlı yamaçların egemen olduğu dağlik bir görüntü kazanmıştır (Şekil 6). Araştırma alanının sayısal arazi modeli Şekil 7'de verilmiştir.

Dereli ilçesinin toprak yapısının, büyük bölümünü, dağlar, ormanlar ve çayırlar kaplamaktadır. İlçe çevresinden başlayan ve orman kesimine kadar uzanan topraklar genellikle kırmızı renkli killi topraklardır. İlçe topraklan dik yamaçlar üzerinde çoğu zaman erozyondan etkilenir. En çok yağmur erozyonu görülür.

Araştırma bölgesi Üst-Kretase volkanik fasiyesli (mineralleri bileşim bakımından her yerde aynı olan yer katmanına verilen ad) arazi çok geniş yer kaplar. Bunun sonucu olarak kıvrımlı ve kırıklı yapılar oluşmuştur (Anonim, 2011).

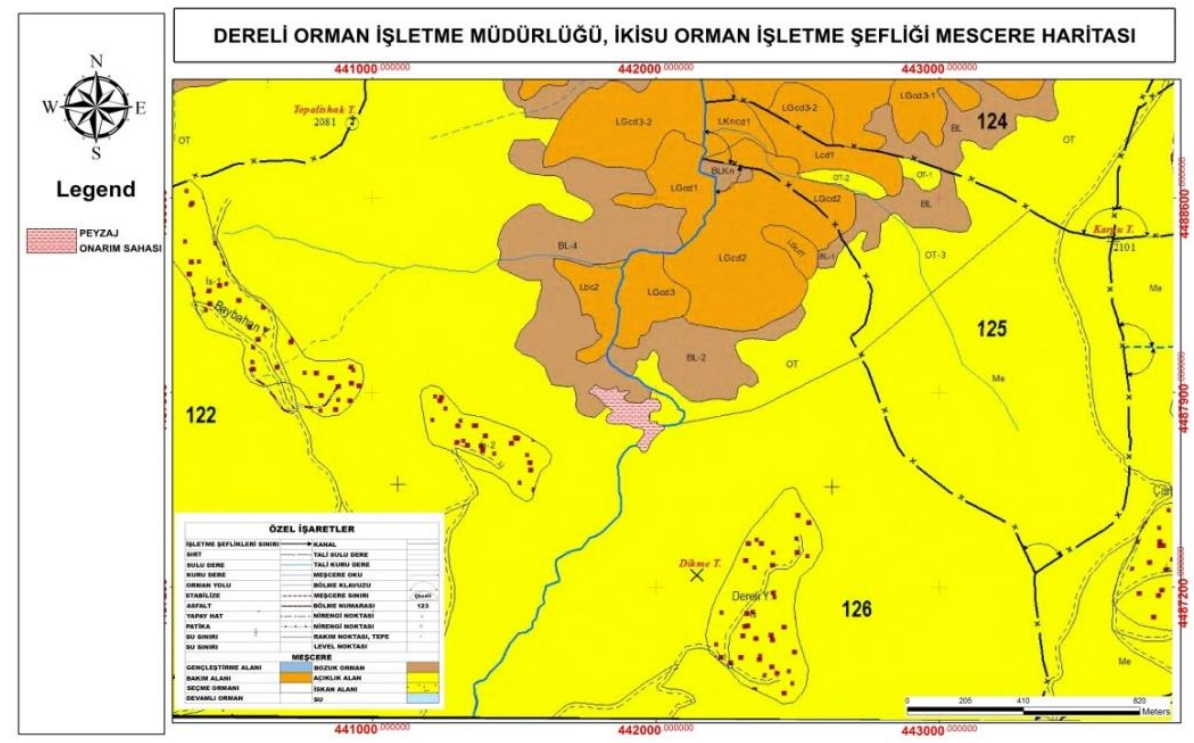

Şekil 4. Araştırma alanı ve yakın çevresinin amenajman haritası
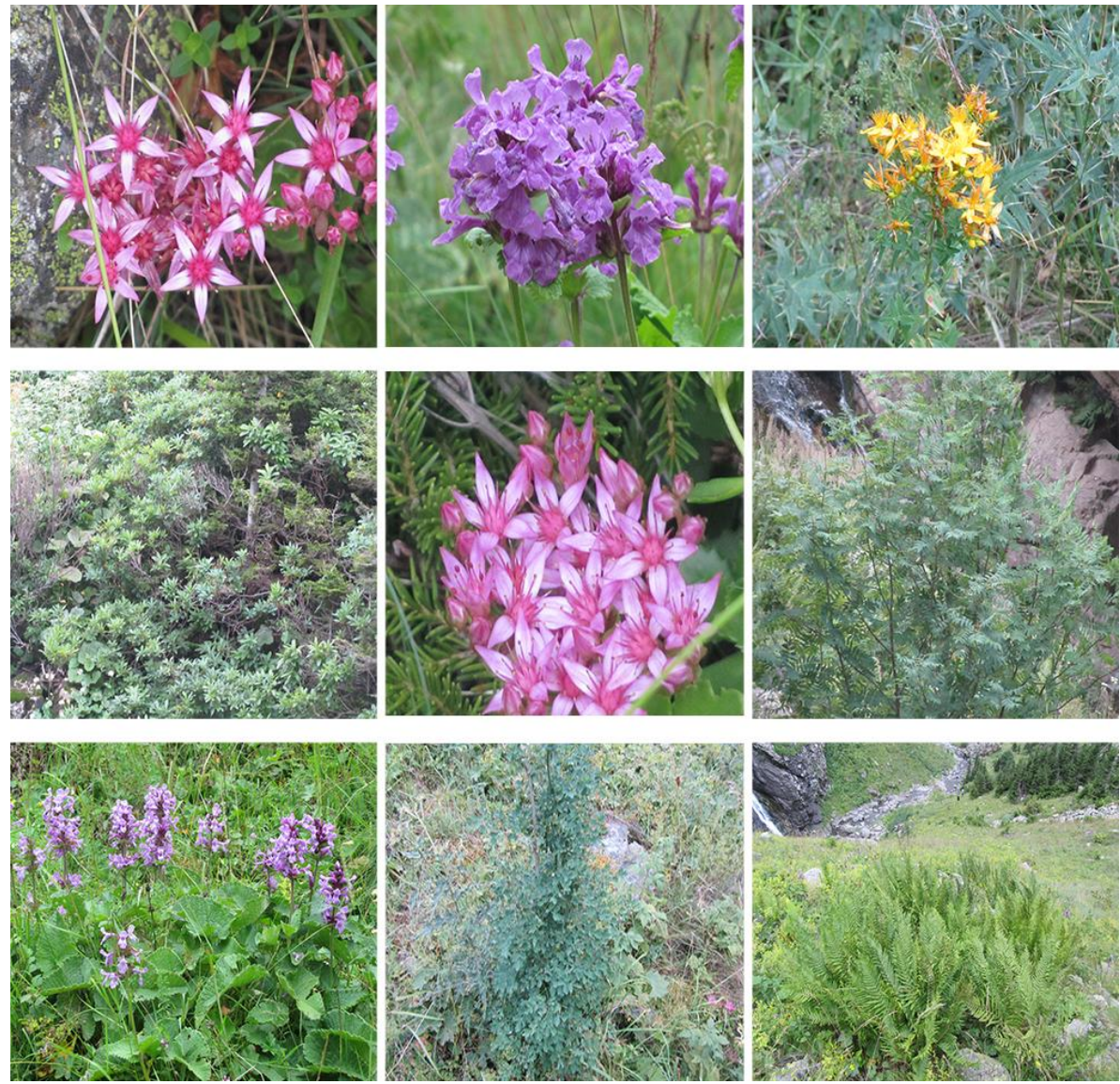

Şekil 5. Araştırma alanından doğal bitki görünümleri 


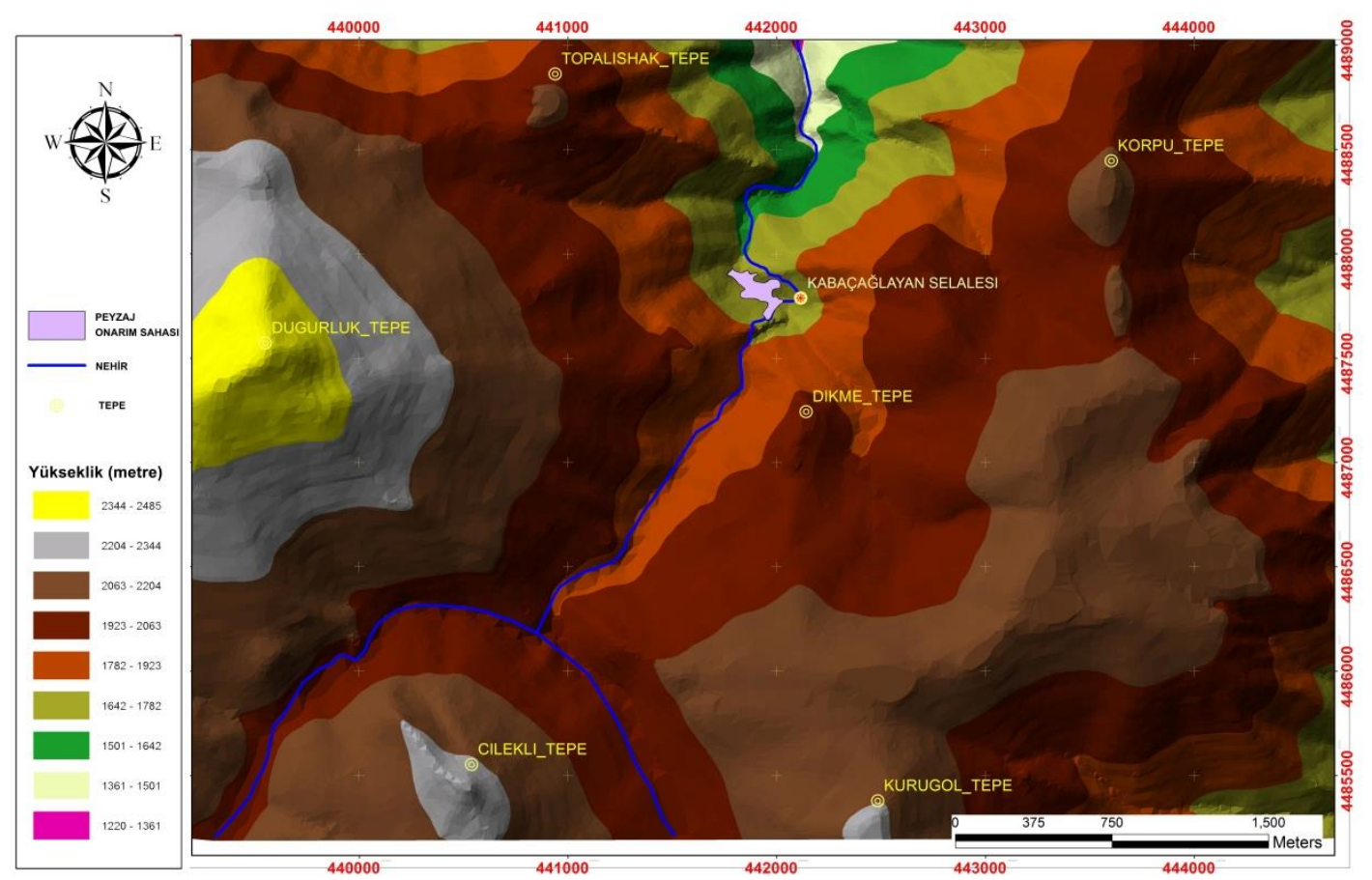

Şekil 6. Araştırma alanı ve yakın çevresinin topoğrafik yapısı

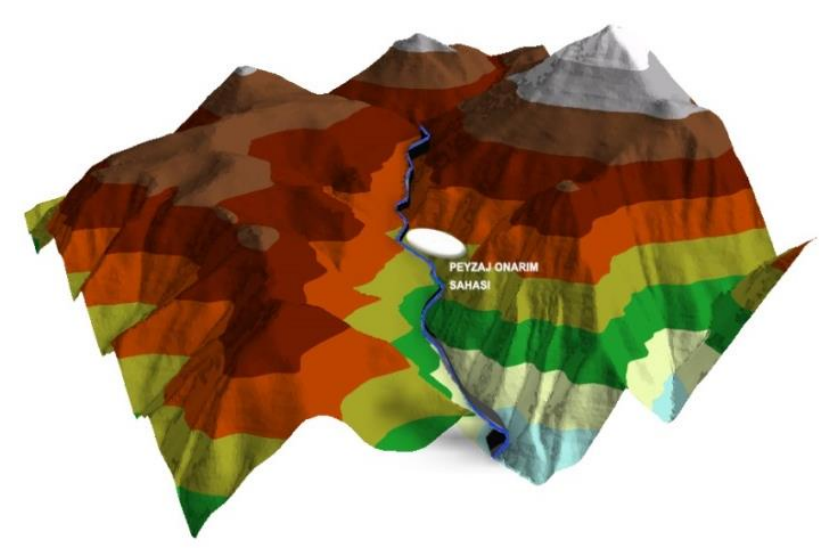

Şekil 7. Araştırma alanı ve yakın çevresinin sayısal arazi modeli

\subsection{Hidrojeoloji}

Araştırma alanı üzerindeki yerüstü su potansiyelini; Karagölbölgesinden doğan Kızıltaş, Sarıyakup, Pınarlar ve Güdül bölgelerinin sularını topladıktan sonra Karadeniz'e dökülen, 60 km uzunluğunda Aksu Deresi'ni besleyen yaklaşık $6530 \mathrm{~m}$ uzunluğundaki Deli Deresi oluş turmaktadir (Şekil 8). Aksu deresi çok sayıda akarsularla beslenmekte, eğim değerinin yüksek olması, yağışların büyük ölçüde akışa geçmesine neden olmaktadır. Aksu deresini önemli derelerden biri olan Deli dere üzerinde kaynaktan (Çilekli tepe yamac1) yaklaşık 1838 m uzaklıkta HES Regulatörü inşa edilmiştir. Baybahan regülatörü kazı fazlası malzeme alanı s ınırları dışında Kabaçağlayan Şelalesi bulunmaktadır (Şekil 9).

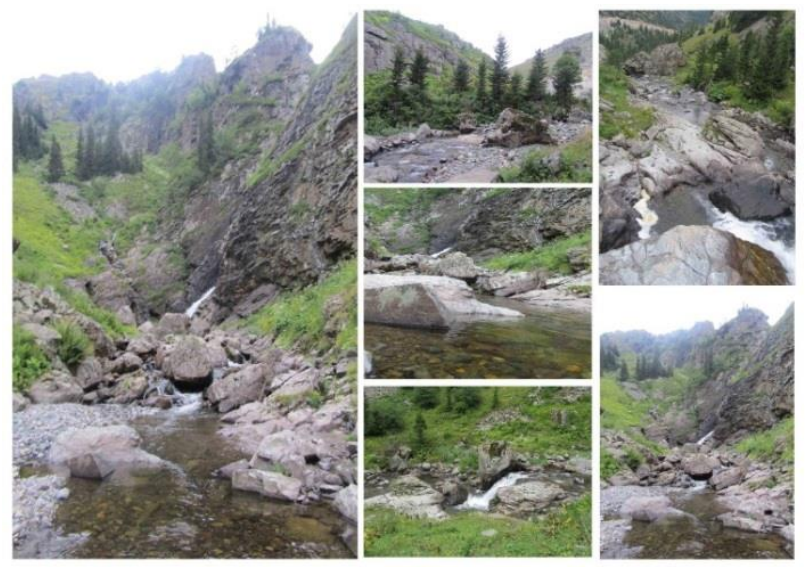

Şekil 8. Deli Deresi çevresinden doğal peyzaj kaynak değerleri
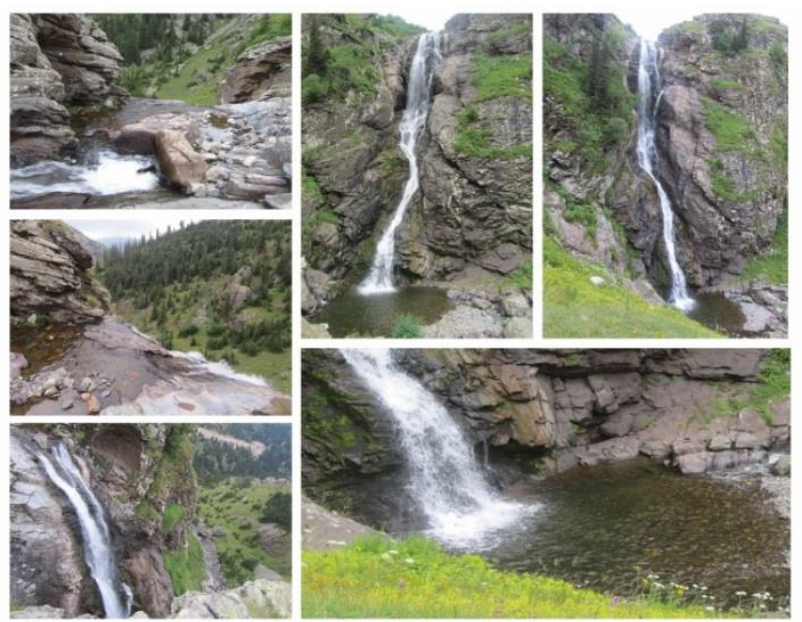

Şekil 9. Kabaçağlayan Şelales inden görünümler 


\subsection{Toprak yaptsl}

Araştırma alanı ve yakın çevresinde iki çeşit toprak grubu görülmektedir. Bunlar Kahverengi Orman Toprakları ve Yüksek Dağ Çayır Topraklarıdır.

Kahverengi Orman Toprakları: Bu topraklar yüksek kireç içeriğine sahip ana madde üzerinde oluşurlar. A (B) C profili olup horizonlar birbirlerine tedricen geçiş yaparlar. Koyu kahverenginde olan A horizonu belirgindir. Gözenekli veya granüler bir yapıya sahiptir. Reaksiyonu kalevi bazen de nötrdür. A horizonundaki organik madde, mineral madde ile iyice karışmıştır. B horizonu daha açık renktedir ve genellikle kahverengidir. Renk bazen kırmızıdır. Reaksiyonları genellikle kalevi bazen de nötrdür. Granüler veya yuvarlak köşeli blok yapıdadır. Çok az miktarda kil birikmesi olabilir. Horizonun aşağı kısımlarında $\mathrm{CaCO}_{3}$ birikmesi görülebilir. Genellikle geniş yapraklı orman örtüsü altında oluşurlar.

Yüksek Dağ Çayır Toprakları: Serin 1lımandan, alpin alanlara kadar yer alan bu topraklar, yüksek enlem derecelerinin ve yüksek irtifa topraklarıdır ve orman sınırının yukarı kesimlerinde bulunur. Çeşitli ana maddeden bozuk drenaj ve soğuk iklim koşullarında gleyleșme ve birazda kalsifikasyon işlemleri yardımı ile oluşmuşlardır. Üstte koyu kahverengi 30-60 cm. kalınlıkta bir A horizonu bulunmaktadır. Bunun altında grimsi ve pas rengi, çizgili ve benekli toprakyer alır. Üzerindeki doğalbitki örtüsü ot, saz ve çiçekli bitkilerdir. Soğuk iklimlerden dolayı verimleri sinırlıdır. Çoğunlukla yazın otlatmada kullanılırlar (Anonim, 2014b).

\section{5. İklim yapısı}

Peyzaj onarım sahası olan Dereli İlçesinde bulunan alanın iklim özellikleri ve koşulları DMİ Genel Müdürlüğü, Giresun Meteoroloji İstasyonundan, temin edilen 1975-2011 yıllarını kapsayan iklim verileri ile ortaya konulmuştur. Alanın ortalama sıcaklığ $14,5^{\circ} \mathrm{C}$, Ortalama yüks ek sıcaklık $17,8{ }^{\circ} \mathrm{C}$, Ortalama düşük sıcaklık $11.9{ }^{\circ} \mathrm{C}$ dir. Alana yağan Ortalama Toplam Yağış Miktarı 1258,2 mm olup, Ortalama Nis pi Nem oranı ise \% 73,2 olarak gerçekleş mektedir.

Proje sahasına en yakın ve proje sahasının iklim özelliklerini en iyi şekilde tanıtabilecek iklim değerleri, Çok Y1llı Ortalama Meteorolojik Değerler Bülteninden alınarak Prof. Dr. Surrı Erinç 'in "Erinç Yağış Etkinliği İndisi” ne göre değ erlendirilmiştir (Çizelge 1).

Alanın; yıllık ortalama yağış: $1258,2 \mathrm{~mm}$, ortalama yüks ek sıcaklık: $14,5^{\circ} \mathrm{C}$ 'dir.

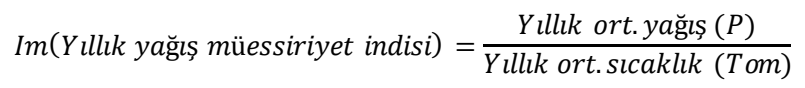

$\operatorname{Im}=\frac{1258,2}{14,5} \quad \operatorname{Im}=86,77$

$>55$ indisli peyzaj onarım sahası; çok nemli orman sınıfı içeris inde yer almaktadır.

\subsection{Değerlendirme ve peyzaj onarım hedeflerinin} belirlenmesi

Giresun İli, Dereli İlçesi, Tepe Köyü, Babahan yaylası sınırları içerisinde HES projesinin, Regülatör yapımı etabında, alana ulaşım için açılan yol ve hafriyatının resmi izinli kazı fazlası malzeme alanına dökülmesi oluşan ve hasar gören peyzajin onarımı gerektiren alanlar bulunmaktadır (Şekil 10).

Baybahan regülatörü kazı fazlası malzeme alanı ve yakın çevresinin Peyzaj Onarım Projesinin hedefi; yol açma çalışmaları ve hafriyatın dökülmes inden kaynaklanan tahrip edilmiş alanların rehabilite edilerek bu alanların ekolojik koşullarının iyileştirilerek şelaleye ulaşımının da sağlandığ eski haline (Şekil 11), dönüştürülmesi olarak belirlenmiştir.

Bu hedefler doğrultusunda; Peyzaj Onarım Projesinde, Kabaçağlayan Şelalesi ve yakın çevresinde planlı bir peyzaj onarımını sağlayabilmek için;

Alanın doğal kaynak değerleri ortaya konulmuş, mevcut durum belirlenmiş, peyzaj onarımına sşık tutacak gerekli veriler tes pit edilmiş tir.

\subsection{Biyolojik ve teknik onarım (biyorestorasyon) süreci}

Peyzaj onarımı yapılacak saha içeris inde onarıma ihtiyaç duyulan Rehabilitasyon alanları $3 \mathrm{kıs}$ m olarak ele alınmıştır. Onarım sahasının uydu görüntüsü Şekil 12 ve 13 'de verilmiştir. Peyzaj Onarım Projesinin hedefleri doğrulusunda uygulanacak aşamalar ise;

1. A ğaçlandırma ve fidan dikimleri,

2. Ağaçlandırma ve fidan dikimleri uygun olmayan aşırı eğimli yamaç şevlerinde "Çelik Ağlarla Şev Koruması Yapilması",

3. Galvanizli kafes tel veya geonet ile çit yapımı gerçekleştirilen yamaçlarda, tesise zarar vermeyecek şekilde en fazla $5 \mathrm{~cm}$ kalınlığa kadar yalancı akasya (Robinia pseudoacacia) tohumu ile karış tırılmış orman toprağının işçi gücüyle yamaçtan aşağıya doğru serilmesi,

4. Şelale için açılan yolun zemin döşemesi,

5. Peyzaj projesinin uygulanmas1,

Rehabilite edilecek alanlarının kapladıkları alanlar Çizelge 2'de verilmiştir.

Çizelge 1. Yağış etkinliği indisi

\begin{tabular}{lcl}
\hline Sinıfi & Índis $(\mathrm{Im})$ & Bitki Örtüsü \\
\hline Tam kurak & $<8$ & Çöl \\
Kurak & $8-15$ & Çöl-step \\
Yarı kurak & $15-23$ & Step \\
Yarı nemli & $23-40$ & Park görünümlü kuru orman \\
Nemli & $40-55$ & Nemli orman \\
Çok nemli & $>55$ & Çok nemli orman \\
\hline
\end{tabular}

Çizelge 2. Peyzaj onarımı alanları

\begin{tabular}{lc}
\hline Rehabilitasyon Alanları & Alan $\left(\mathrm{m}^{2}\right)$ \\
\hline Rehabilitasyon Alanı I & $5.719,67$ \\
Rehabilitasyon Alanı II & $3.936,93$ \\
Rehabilitasyon Alanı III & $3.915,43$ \\
Şelale yolu & $1.055,78$ \\
Toplam & $14.627,81$ \\
\hline
\end{tabular}




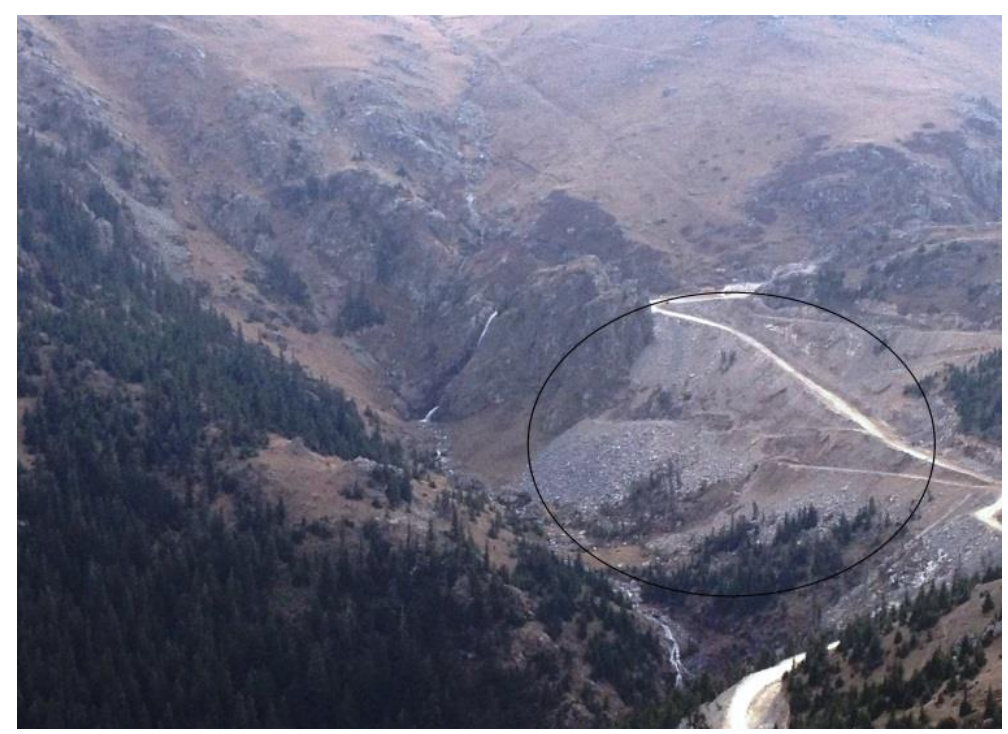

Şekil 10. Peyzaj onarımı yapılacak sahadan görünüm

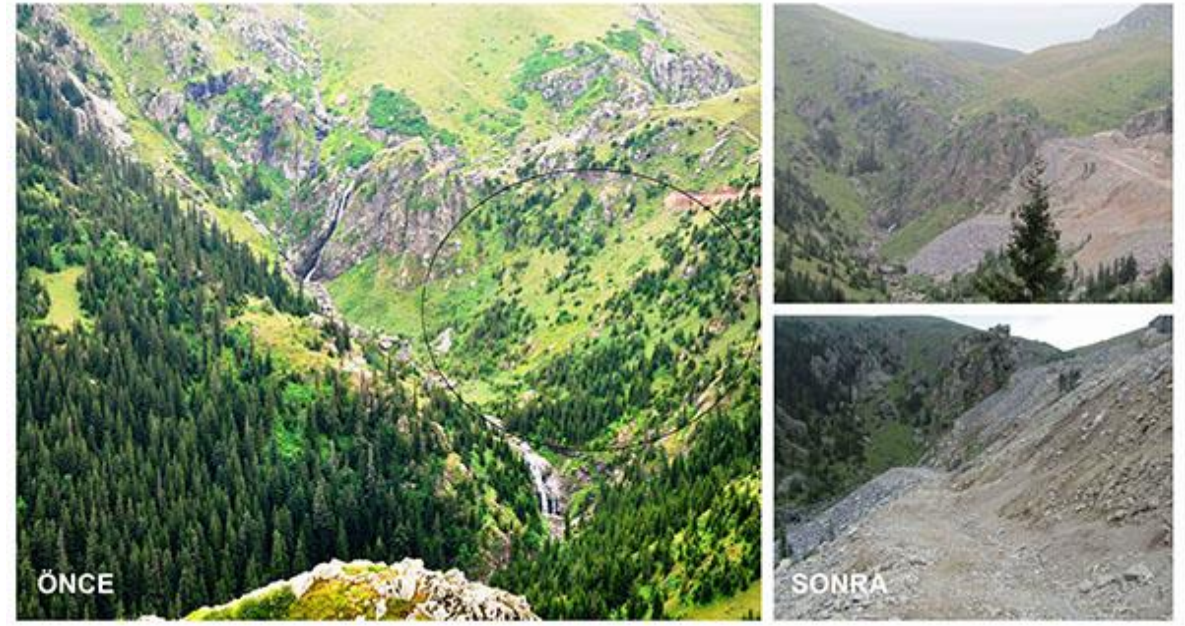

Şekil 11. Peyzaj Onarım sahasının tahrip edilmeden ve edildikten sonraki görünümleri

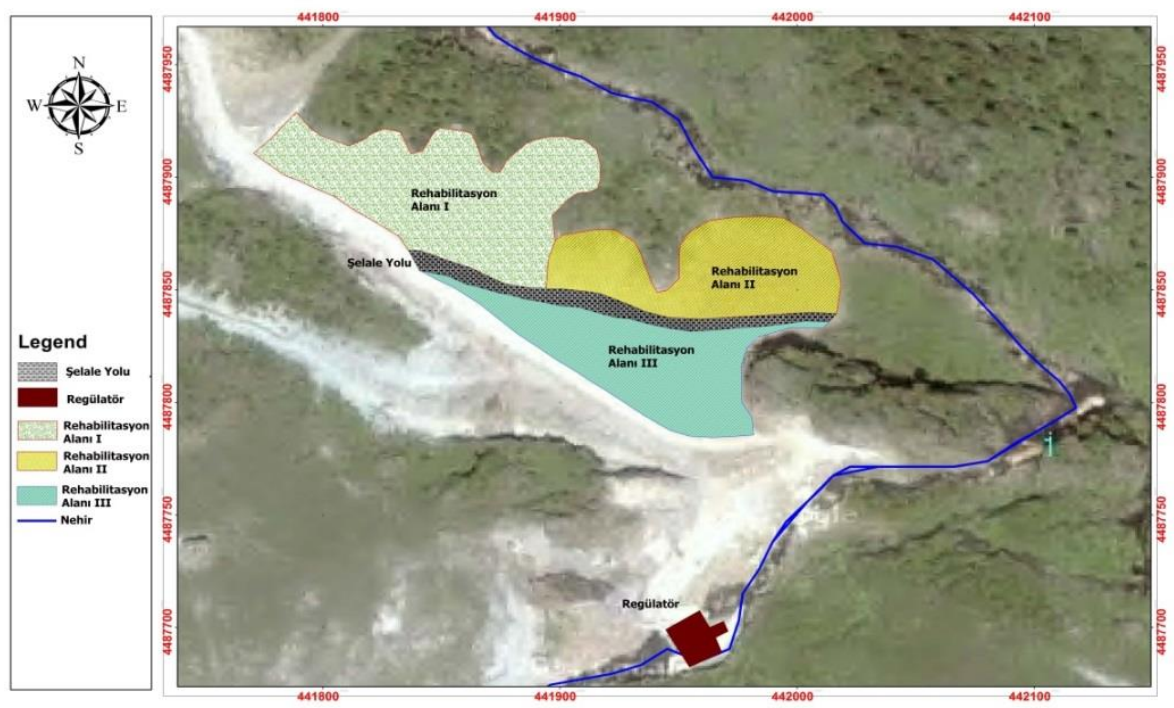

Şekil 12. Peyzaj onarımı yapılacak sahanın uydu görüntüsü 


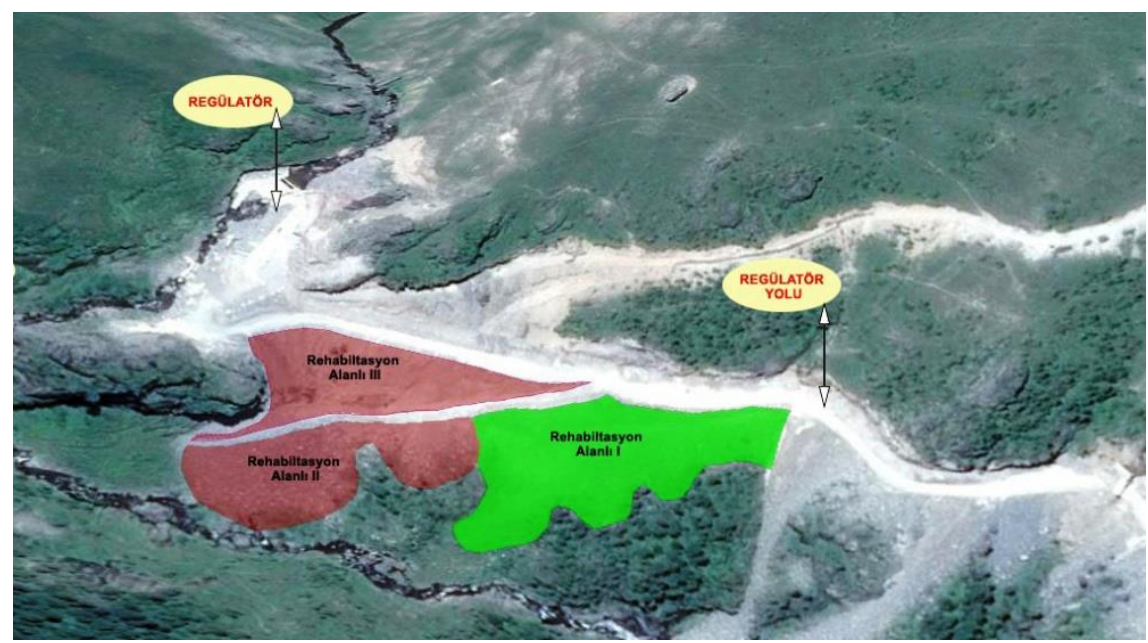

Şekil 13. Peyzaj onarımı yapılacak sahanın 3D uydu görüntüsü

\subsection{1 Ăgaçlandırma ve fidan dikimleri}

Peyzaj Onarım alanında ağalandırma ve fidan dikimi yapılacak alan yalnızca; Rehabilitasyon Alanı I (5.719,67 $\mathrm{m}^{2}$ )'lik alanda yapılacaktır. Fidan dikim alanına alanın hâkim türü olan doğu ladini yapraklı orman ağac1 önerilmiştir. Ayrıca alana mürver ve süs üvezi (Sorbus aucuparia L.) 'ne de yer verilmiştir.

Dikim yapılacak alanda karışık dikim şeklinde tüplü fidan dikimi önerilmiştir. Ağaçlandırmada alanında, dikimin temel ağaç türü olan doğu ladini ile birlikte \% 10 oranlarında ayrı ayrı gruplar halinde mürver ve süs üvezi dikimi alana gruplar halinde, alanın \% 20'sini kaplayacak şekilde dikilmesi önerilmiştir.

Dikimler $3 \times 3 \mathrm{~m}$ aralık ve mesafelerle (hektara 1111 tane fidan) dikim uygulaması şeklinde gerçekleştirilmesi hedeflenmiştir. Dikilecek fidan adedi (Çizelge 3)'de belirtilmiştir. Dikim için toplam fidan adedi 635 olarak hesaplanmıștır.

Onarım sahasında önerilen mürver ve süs üvezi için ahşap herek uygulaması (uzunluğu en az $1 \mathrm{~m}$.) yapılması gerekliliği vurgulanmıştır.

\subsection{2. Çelik ăglarla şev koruması yapılması}

Toprak derinliğinin ve yapısının teras yapımına müsait olmadığ 1 arazi meylinin genellikle $\% 60$ ve üzerinde olduğu alanlarda yamaç stabilizasyonunun sağlanması için çelik ağlarla şev koruması yapılmaktadır. Peyzaj Onarım sahasında Rehabilitasyon Alanları II ve III'de çelik ağlarla şev koruması yapılması önerilmiştir. Çelik ağlarla yapılacak şev korumas1 için toplam alan $7.852,36 \mathrm{~m}^{2}$ lik bir alan öngörülmektedir.

Kullanılacak sistem, max. $0.50 \mathrm{~m}$ çapında düşmesi muhtemel kayalıkların bulunduğu yamaç boyunca serilir. Çok sarp ve dik yamaçlarda tel ağ şev üstüne tepe ankrajlar ile sabitlenmelidir. Bu uygulamalar düşen kaya ve taş parçalarının kontrollü olarak şev dibine inmes ini sağlar. Tel ağ ve şev arası mesafe sinırlandırmak istendiğinde tel a $\breve{g}$ yüzeye ankraj veya çivilerle tutturulmalıdır (Şekil 14).

Ankrajlama yapılırken dikkat edilmesi gereken en önemli nokta, düşen kaya ve taş parçalarının güvenli şekilde aşağıya inmesini engellemeyecek şekilde olmasıdır. Çift bükümlü çelik tellerden imal edilmiş ağlardan yapılmalıdır. Tek bükümlü çelik tellerden imal edilmiş ağlar hasar gördüğünde aynı emniyeti sağlayamamaktadırlar (Anonim, 2012).

Rehabilitasyon Alanları II ve III'de yapılacak olan kaya ve taş düşmesine karşı çelik ağlarla şev koruması projesine göre, çelik ağlarla şev koruması yapılmalıdır. Çelik ağların düşey zemine hangi aralıklar ve bulon deliği mesafesinde olacağ1 ise yapılacak olan zemin etüdü sonucu ayrıca yapılacak olan Kaya Bulonu projesi ile belirlenmelidir.

\subsection{3. Çit yapımı gerçekleştirilen yamaçlarda orman topră̆ı serilmesi}

Galvanizli kafes tel veya geonet ile çit yapımı gerçekleș tirilen yamaçlarda, tes is e zarar vermeyecek ș ekilde en fazla $5 \mathrm{~cm}$. kalınlığa kadar orman toprağ 1 serilmesi için gerekli olan orman toprağı sahanın güneyinde bulunan yerleşim alanına giden patika yolun geniş letilmes inden elde edilecek üst toprak ile gerçekleştirilmesi önerilmektedir.

Yol açılmasından elde edilecek orman toprağ 1 yalancı akasya tohumu ile karıștırılarak ve ișçi gücüyle yamaçtan aşağıya doğru serpme yoluyla ekim yapılmalıdır. Serpme usulü ile ekim için $5 \mathrm{~kg}$. tohum kullanılması gerekliliği ortaya konulmuştur.

\subsubsection{Kazı fazlası malzeme alanı için açılan yolun zemin döşemesi}

Kazı fazlası malzeme alanı için açılan $1.055,78 \mathrm{~m}^{2}$ yolun 4 $\mathrm{cm}$ kalınlıkta andezit plaklarla döşeme $(30 \mathrm{~cm}$ x serbest boy) ile kaplaması yapılmalıdır.

Çizelge 3. Dikilecek fidan adedi

\begin{tabular}{llccr}
\hline Tür & Latince adı & Yaşı & $\begin{array}{l}\text { Aralık } \\
\text { mesafe }\end{array}$ & Adet \\
\hline Doğu Ladini & Picea orientalis L. & $3+0$ tüplü & $3 \times 3$ & 507 \\
Mürver & Sambucus nigra L. & $3+0$ tüplü & $3 \times 3$ & 64 \\
Süs üvezi & Sorbus aucuparia L. & $3+0$ tüplü & $3 \times 3$ & 64 \\
\hline Toplam & & & 635 \\
\hline
\end{tabular}

3.7.5. Peyzaj tasarım projesi 
Peyzaj çalışma alanını, kazı fazlası malzeme alanına ulaşımı sağlayan ulaşım yolu ve çevresi için hazırlanmıştır. Öncelikle elde edilen, belge ve dokümanlardan yararlanılarak alanın mevcut durumu, sorunları ve sahip olduğu kaynak değerleri ortaya konulmuştur. Daha sonra Kabaçağlayan şelalesine ulaşım sağlayan yolun peyzaj tasarımının gerçekleştirilebilmesi için mevcut alt haritalar sayıs allaştırılmıştır.
Arazi çalışmaları ile gözlem ve incelemelerle elde edilen veriler doğrultusunda bilgisayar ortamında AutoCAD, ArcGIS ve SketchUp programları yardımıla tasarım çalışmaları gerçekleştirilmiştir. Peyzaj onarım sahasından elde edilen veriler ve analiz sonucunda amaçlara uygun mekânsal peyzaj tasarım paftaları (1/100 ölçekli) plantasyon ve ölçülendirme ve detay paftaları (1/100 - 1/20 ölçekli) oluşturularak alanın gelecekteki kullanımına iliş kin ilkeler ve öneriler sunulmuştur. Peyzaj projesi ve perspektif paftalarından örnekler Şekil (15-16)'da sunulmuştur.
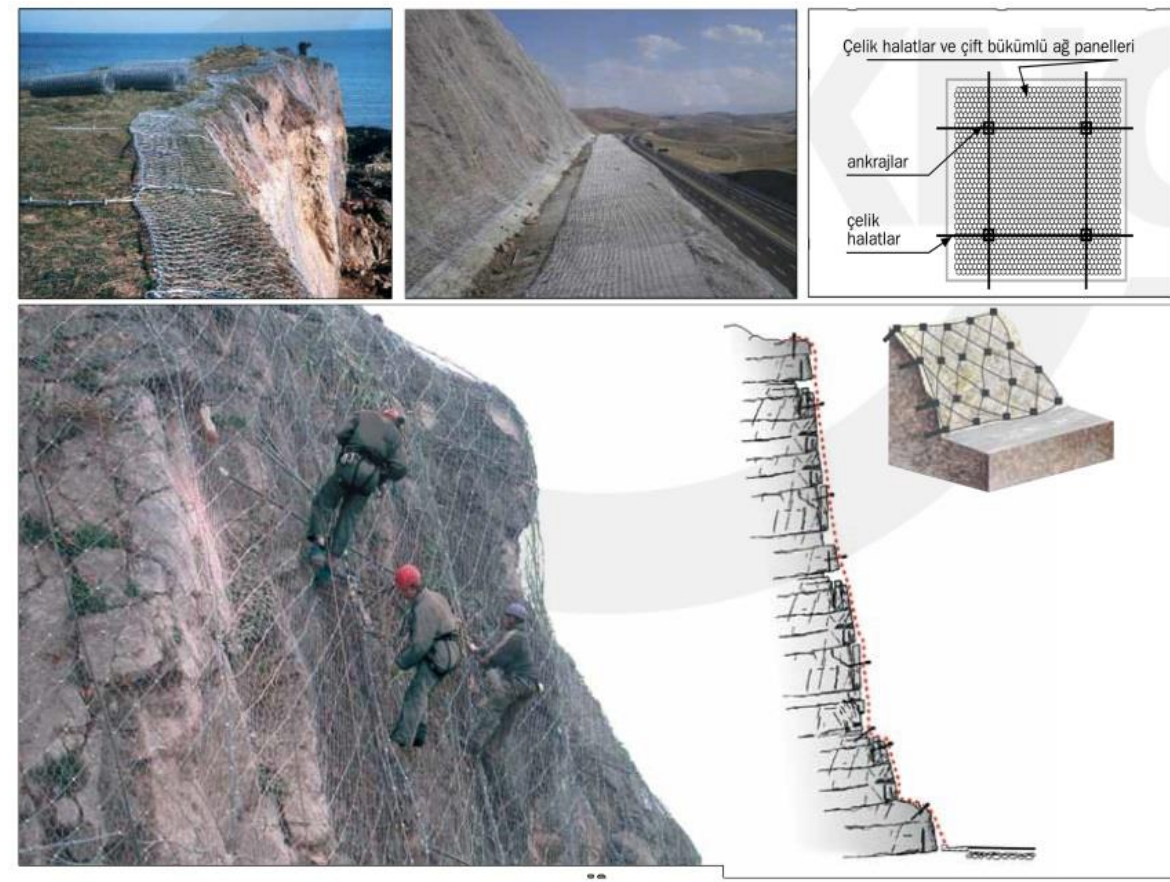

Şekil 14. Çelik ağlarla şev koruması yapılmasından görünümler (Anonim 2012)
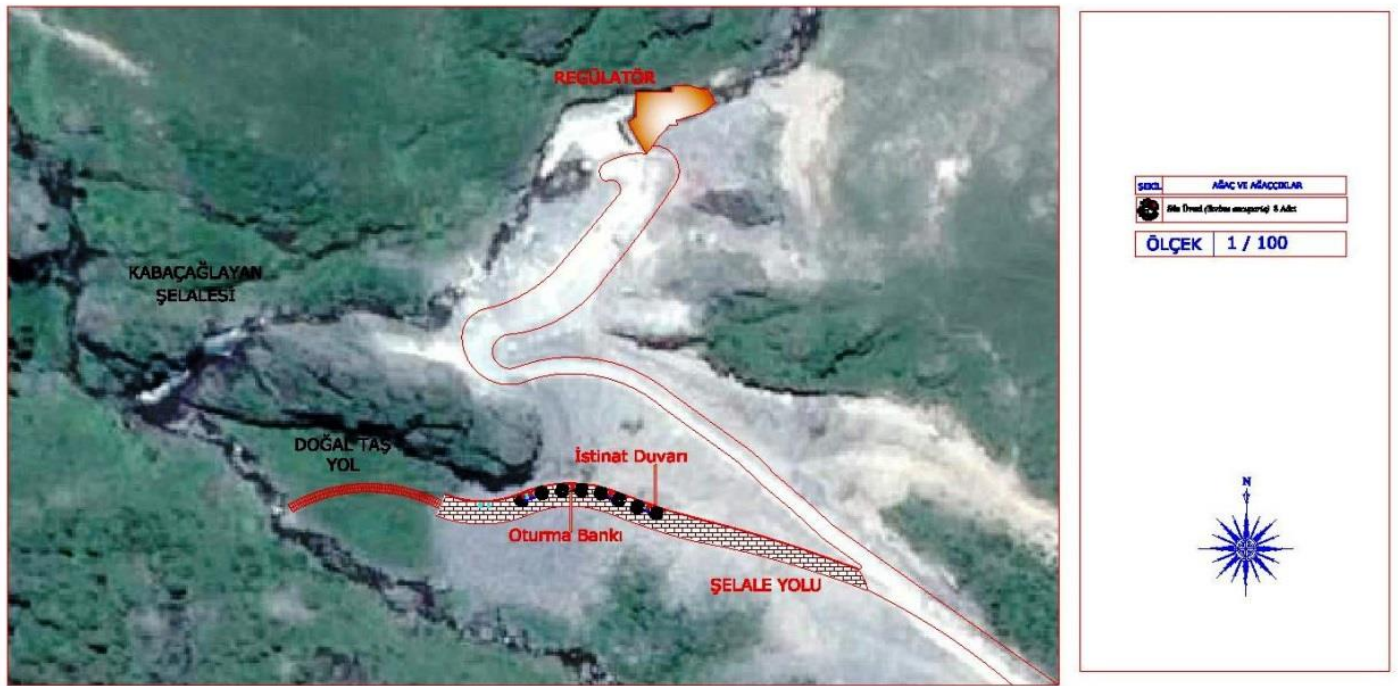

Şekil 15. Peyzaj tas arım projesi 

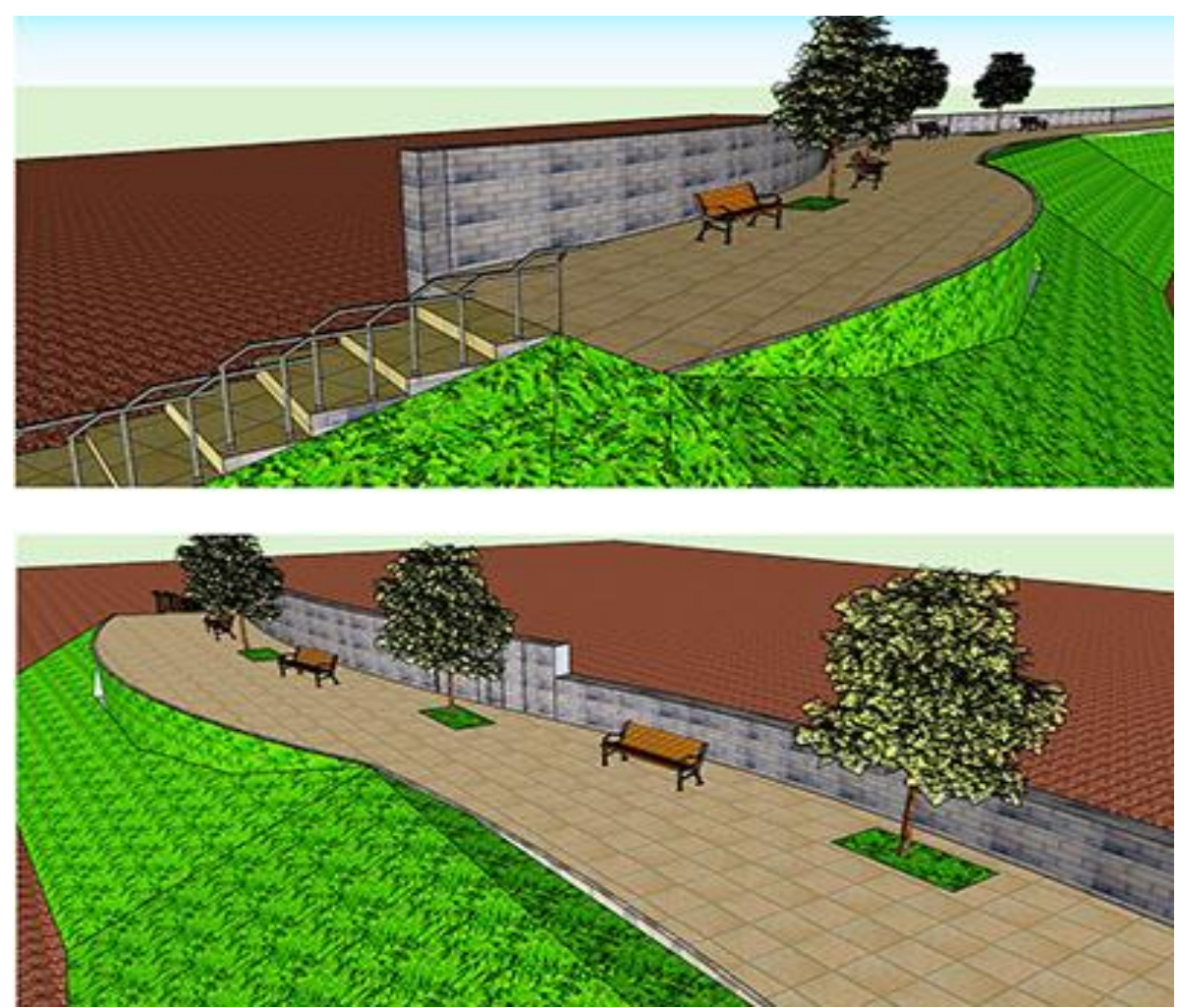

Şekil 16. Peyzaj tasarım projesi

\section{Sonuç}

HES projelerinde çevresel sorunların başında gelen iki ana unsur olan, tesis aşamasında doğaya verilen zarar ile dereye birakılması planlanan can suyu miktarları büyük önem taşımaktadır.

$\mathrm{Bu}$ çalışma kapsamında Giresun ili sınırlarında bulunan Kabaçağlayan Şelalesi örneğinde, benzer alanlar için biyolojik onarımda izlenmesi gereken yöntem aşamalarına yer verilmiştir. Ortaya konulan yöntem ile bundan sonraki uygulamaya yönelik olarak bir örnek olabilecektir. Yapılan proje ile toplam $14.627,81 \mathrm{~m}^{2}$ alanın islah edilmesi planlanmıştır. Rehabilitasyon alanı içeris inde ağaçlandırma, çelik ağlarla şev koruması planlanmış ve onarım sahasının için peyzaj projesi çizilmiştir.

Peyzaj onarım çalışmaları sonrası doğanın kendini onarması çok uzun yıllar almaktadır. Bu kapsamda alanda seçilecek bitki türlerinin çeşitleri, dağılımları ve alana özgü bitki türleri seçimi bu süreyi etkileyen en önemli konuların başında gelmektedir. Yapılan çalışmada onarım sahasının eski haline getirilmesi amaciyla alana özgü bitki türleri seçimi yapılmıştır. Alanın doğalvejetas yonu içeris inde olan ve rehabilitasyon projesinde temel bitki türü olarak seçilen ve tüplü fidan olarak uygulanacak olan doğu ladininin (Picea oriantalis), doğal peyzaja tamanlamıla uyumlu hale gelebilmesi için 8-10 yıllık bir sürece ihtiyaç duyulacaktır. Çelik ağlarla şev koruması yapılan ve orman toprağı ile yalancı akasya tohumunun karıştırılarak yüzeye serilmesi şeklinde planlanan alandaki rehabiltasyon çalışmasının başarısı ise; 2-3 yıllık bir dönem içerisinde kendini gösterecek ve peyzaja verilen tahribatın giderilmesi hedeflenmiştir.
Günümüzde yapılmakta olan enerji ve madencilik faaliyeteler sonrası onarımve planlama çalışmalarında farklı meslek disiplinleri bir arada çalışmaktadır. Onarım plan ve uygulamaları çok disiplinli yaklaşımla yapılmalı, stabilizasyon için toprak mekanikçis i, toprak verimliliği için toprak bilimcisi, yüzey ve yeraltı suları için hidrojeolog, temel bilimler için ekolog ve alan kullanım planlaması için peyzaj mimarları katılmalıdır (Ulus oy ve Ayaş lıgil, 2012).

\section{Kaynaklar}

Acar, E., Doğan, A., 2008.Türkiye'nin hidroelektrik enerji potansiyeli ve çevresel etkilerinin değerlendirilmesi. VII. Ulusal Temiz Enerji Sempozyumu, 17-19 Aralık 2008, İstanbul, s. 675-682.

Akpınar, N., Çelem, H., 2000. Madencilik sonras1 peyzaj onarımında alan kullanım planlamasına yönelik bir yöntem: En yüksek değerler haritası yaklaşımı. Peyzaj Mimarlığ1 Kongresi, 19-21 Ekim 2000, Ankara, s. 383391.

Aksungur, M., Ak, O., Özdemir, A., 2011. Nehir Tipi Hidro. Santrallerinin Sucul Ekos isteme Etkisi: Trabzon Örneği, Journal of Fisheries Sciences, 5(1): 79-92.

Anonim, 2011. Çevre ve Temiz Enerji: Hidroelektrik. Çevre ve Orman Bakanlığ , Devlet Su İşleri Genel Müdürlüğü, Ankara.

Anonim, 2012. Kaya ve Taş Düşmesine Karşı Koruma Uygulamaları, Problemler ve Çözümler. Tekno Maccaferri Çevre Teknolojileri, Mühendislik San. ve Ticaret A.Ş. İstanbul,http://www.tekno.com.tr/ images/ gnel/2622013121812843.pdf, Erişim Tarihi: 16.08.2016 
Anonim, 2013. Giresun Orman Bölge Müdürlüğünün, Dereli Orman İşletme Şefliği, İkisu Orman İşletme Şefliği Amenajman haritaları, Giresun.

Anonim, 2014a. Dereli Kaymakamlığ1 resmi web sayfası. http://www.dereli.gov.tr/. Erişim Tarihi: 15.08.2016

Anonim, 2014b. Giresun İli, Alucra İlçesi, Çakrak Köyü, Yağlıdere İlçesi, Akpınar Köyü, Çakrak Deresi Üzeri, Göktepe Regülatörü ve HES Projesi. TENET Enerji A.Ş.

Demir, M., Güven, M., 2015. In the Context of Energy Policy on Turkey; Evaluation of Environmental Impact of Hydroelectric Power Plants (HPP). 16-19 September 2015, Florence, Italy, pp. 192-204

Deniz, M., Şen, İ., 2011. AKFEN HES, Saraçbendi HES Erozyon Kontrolü ve Restorasyon Uygulama Projesi, T.C. Orman ve Su İşleri Bakanlığ 1 , Çölleşme ve Erozyonla Mücadele Genel Müdürlüğ̈̈, Ankara.

Kocadağistan, M.E., Kırzıoğlu, M.I., Kocadağistan, B., 2007. Kum Ocağ1 İşletmesinin Yeniden Doğaya Kazandırılmas1; Esendere Kum Ocağ1 Örneği, Gaziosmanpaşa Üniversitesi Ziraat Fakültesi Dergisi, 1: 9-18.
Özbey, D., 2005. Açık Ocak Madenciliği Sonrası Onarım Çalışmalarında Peyzaj Mimarlarının Rolü. Madencilik ve Çevre Sempozyumu, 5-6 Mayıs 2005, Ankara, s. 6972 ,

Ulusoy, Y., Ayaşlıgil, T., 2012. Açık Maden Ocaklarının Rehabilitasyonu ve Doğaya Yeniden Kazandırılmas inın "Şile-Avc1koru" Örneğinde İrdelenmesi. Istanbul University Journal of the Faculty of Forestry, 62 (2): 2136.

Uzun, O., Yılmaz, O., 2009. Düzce Asarsuyu Havzas1 Peyzaj Değerlendirmesi ve Yönetim Modelinin Geliştirilmesi, Ankara Üniversitesi Zıraat Fakültesi, Tarım Bilimleri Dergisi, 15(1):79- 87.

Ürker, O., Çobanoğlu, N., 2012. Türkiye'de Hidroelektrik Santrallerin Durumu (HES) ve Çevre Politikaları Bağlamında Değerlendirilmesi, Ankara Üniversitesi Sosyal Bilimler Enstitüsü Dergisi, 3(2):65-88. 